\title{
Growth and production potential of pigeonpea (Cajanus cajan L.) as influ- enced by intercropping and integrated nutrient management
}

\author{
A. K. Pal ${ }^{1}$, R.S. Singh ${ }^{2}$, U. N. Shukla ${ }^{2}$ and Smita Singh ${ }^{2}$ \\ ${ }^{1}$ Department of Agronomy, Faculty of Agriculture, Bidhan Chandra Krishi Viswavidyalaya, Mohanpur, Nadia- \\ 741252 (West Bengal), INDIA \\ ${ }^{2}$ Department of Agronomy, Institute of Agricultural Sciences, Banaras Hindu University, Varanasi-221005 (Uttar \\ Pradesh), INDIA \\ *Corresponding author. E-mail: akpal07@gmail.com
}

Received: May 30, 2015; Revised received: October 10, 2015; Accepted: February 10, 2016

\begin{abstract}
A field experiment was conducted during the rainy season of 2010-11 at Varanasi to evaluate the production potential of pigeonpea (Cajanus cajan L. Mill sp.) in intercropping with different fertility levels. The pigeonpea+urdbean intercropping system exhibited its superiority by recording higher growth attribute i.e. plant height $\left(231.22 \mathrm{~cm}_{\text {plant }}{ }^{-1}\right)$, no. of branches $\left(18.20\right.$ plant $\left.^{-1}\right)$, dry matter accumulation (213.25 g plant $\left.{ }^{-1}\right)$, LAl (3.45), yield attribute i.e. no. of pods $\left(135.57\right.$ plant $\left.^{-1}\right)$, no. of grain $\left(4.06\right.$ pod $\left.^{-1}\right)$, Test weight $(106.07 \mathrm{~g})$, and yield i.e. grain yield $\left(1792.29 \mathrm{~kg} \mathrm{ha}^{-1}\right)$ and stalk yield $\left(7614.97 \mathrm{~kg} \mathrm{ha}^{-1}\right)$. Application of $100 \%$ recommended dose of fertilizer (RDF)+2.5t VC fertility level recorded its superiority by recording higher growth attribute i.e. plant height $\left(232.42 \mathrm{~cm} \mathrm{plant}^{-1}\right)$, no. of branch (19.07 plant ${ }^{-1}$ ), dry matter accumulation (214.65 g plant ${ }^{-1}$ ), LAl (3.62) and yield attributes i.e. no. of pods $\left(141.42\right.$ plant $\left.^{-1}\right)$, no. of grain $\left(4.13\right.$ pod $\left.^{-1}\right)$ and test weight $(108.22 \mathrm{~g})$ and yield i.e. grain yield $\left(1831.82 \mathrm{~kg} \mathrm{ha}^{-1}\right)$, and stalk yield $\left(8221.61 \mathrm{~kg} \mathrm{ha}^{-1}\right)$ over all fertility levels. In the cultivation of long duration crops, the short duration crop may be used as intercrop to generate additional income for farmers' and INM practices also reduce cost of fertilizer as well as environmental pollution.
\end{abstract}

Keywords: Economics, Fertility levels, Intercropping systems, Pigeonpea, Yield

\section{INTRODUCTION}

Pigeonpea (Cajanus cajan L. Mill sp.) is an important pulse crop of dry land agriculture because of its ability to produce economic yield under limited moisture condition. It occupies an area of about $3.86 \mathrm{~m}$ ha with a total production $2.9 \mathrm{~m}$ ton with an average productivity of $751 \mathrm{~kg} \mathrm{ha}^{-1}$ (GOI, 2011). Intercropping is an age old practice being followed by subsistence farmers to achieve their domestic needs and also monetary benefits to some extent. The main advantage of intercropping is that the component crops are able to use growth resources differently and make better overall use of growth resources than grown separately. The success of any intercropping system depends mainly on selection of component crops. The component crops should invariably have different growth rhythms and rooting patterns. Pigeonpea is a tall growing; wide spaced crop with deep root system which can accommodate short duration cereals and pulses which is having shallow root system and utilized benefit of initial slow growth of pigeonpea. Growing of blackgram or sorghum as intercrop helps to sustain the productivity and the system would prove to be a viable intercropping system. Therefore, to increase the productivity of the pulses per unit area particularly in rainy (kharif) season, inter- cropping of short duration crops seems an alternative (Kumawat et al., 2012).

Continuous use of only chemical fertilizers in intensive cropping system is leading to imbalance of nutrients in soil, which has an adverse effect on soil health and also on crop yields. Since fertilizer nutrients constitute a major costly production inputs, exploitation of yield potentiality of this crop depend on how effectively and efficiently this input is managed. Moreover, high fertility levels not only put a heavy financial burden to the growers but gradually decrease the partial productivity and thereby, jeopardize the sustenance of the basic system of production. On the other hand, the large scale use of only chemical fertilizers as a source of nutrients has less use efficiency. Besides low, variable and generally unbalanced nutrient contents, it is difficult to provide the proper nutrient balance to meet crop requirements with bulky organic manure (Kumar and Rana, 2007). On the other hand, continuous use of organics helps to buildup soil humus and beneficial microbes besides, improving the soil physical properties. But use of organics alone does not result in spectacular increase in crop yields due to their low nutrient content and also availability. Organic manures with recommended dose of fertilizers have been reported to be beneficial in augmenting the yield of pigeonpea 
(Singh, 2007). The lack of information on these aspects under rainfed conditions made as impetus to undertake the present study and carried out to examine the production potential and economics of pigeonpea (Cajanus cajan L.) under different intercropping system and fertility levels.

\section{MATERIALS AND METHODS}

A Field experiment was conducted during rainy (kharif) of 2010-11 at the Agricultural Research Farm, Institute of Agricultural Sciences, Banaras Hindu University, Varanasi. It is located on at latitude of $25^{\circ} 18^{\prime}$ $\mathrm{N}$, longitude of $83^{\circ} 03^{\prime} \mathrm{E}$ and altitude of 128.93 meters above mean sea level. The annual rain fall of Varanasi is $586.3 \mathrm{~mm}$ and more than $80 \%$ generally occurs during the south-west monsoon (July-September). The soil of experimental plot was sandy clay loam $(8.48 \%$ coarse sand, $53.97 \%$ sand, $19.51 \%$ silt and $17.89 \%$ clay) in texture using by Hydrometer method (Bouyoucos, 1962). The soil had $189.80 \mathrm{~kg} \mathrm{ha}^{-1}$ alkaline permanganate oxidizable N (low) using by Alkaline permanganate (Subbiah and Asija, 1956), $19.5 \mathrm{~kg}$ $\mathrm{ha}^{-1}$ available $\mathrm{P}$ (medium) using by $0.5 \mathrm{~N}$ NaHCO3 extractable (Olsen et al, 1954), $200.3 \mathrm{~kg} \mathrm{ha}^{-1} 1 \mathrm{~N}$ ammonium acetate exchangeable $\mathrm{K}$ (medium) using by Ammonium acetate extractable flame photometer (Jackson, 1973), 0.33\% organic carbon (low) using by Walkley and Black's Method (Jackson, 1967) with 7.6 $\mathrm{pH}$ of soil (1:2.5 soil water ratio) using by Glass electrode pH meter (Jackson, 1973). Geographically, experimental site falls under sub-tropical zone of IndoGangatic plains and lies on the left bank of river Ganga. The experiment was laid out in three times replicated Factorial randomized block design where main plot received six combination of two intercropping system (IS 1 -Pigeonpea+sorghum and $\mathrm{IS}_{2}$ Pigeonpea+urdbean) and subplot assigned six fertility levels $\left[\mathrm{F}_{1}-100 \%\right.$ recommended dose of fertilizer (RDF), $\mathrm{F}_{2}-100 \% \mathrm{RDF}+$ vermicompost (VC) @ $2.5 \mathrm{t}$ ha ${ }^{-1}, \mathrm{~F}_{3}-100 \% \mathrm{RDF}+$ phosphorus solubilizing bacteria (PSB)+ Rhizobium, $\mathrm{F}_{4}-50 \%$ RDF, $\mathrm{F}_{5}-50 \%$ RDF+ vermicompost@2.5 t ha ${ }^{-1}$ and $\mathrm{F}_{6}-50 \% \mathrm{RDF}+\mathrm{PSB}+$ Rhizobium] were allotted, recommended dose of fertilizer (Nitrogen: Phosphorus: Potassium = 30:60:20). The recommended dose of fertilizer and vermicompost was applied in furrow at the time of sowing. The N, P and $\mathrm{K}$ content of vermicompost were $1.4,0.37$ and $0.40 \%$, respectively. Seed treatment was given before sowing of crop. The whole field was divided into three blocks each representing a replication. Crops were grown as per recommended package of practices. The urdbean (Pant U-19) @10 kg ha-1, sorghum (GK-4031) local cultivar@12 kg ha ${ }^{-1}$ and pigeonpea (Bahar)@15 $\mathrm{kg} \mathrm{ha}^{-1}$ were sown on second fortnight of July. The sowing was done on $27^{\text {th }}$ July 2010. Fertilizer was drilled in bands $8-10 \mathrm{~cm}$ below the surface. Full dose of nitrogen phosphorus and potassium were applied as per treatments through urea, Di-ammonium phosphate and murate of potash, respectively just before sowing of crops. All the data pertaining to the present investigation were statically analyzed as per the methods described by Gomez and Gomez (1984). The statically significance of various effects was tested at 5 per cent level of probability. The data recorded were analyzed as per analysis of variance technique for factorial randomized block design.

\section{RESULTS AND DISCUSSION}

Growth attributes: Intercropping and different fertility levels were found to have significant influence on growth characteristics of pigeonpea (Table 1). The pigeonpea+urdbean intercropping recorded significantly taller plants $\left(231.22 \mathrm{~cm}\right.$ plant $\left.^{-1}\right)$, number of branches $\left(18.20\right.$ plant $\left.^{-1}\right)$, plant dry matter $(213.25 \mathrm{~g}$ plant $^{-1}$ ), LAI (3.45), effective root nodule plant ${ }^{-1}$ (23.58), Days to maturity (263) and nodule dry weight $\left(183.96 \mathrm{mg} \mathrm{plant}^{-1}\right)$ than pigeonpea+urdbean intercropping system recorded the highest values of above growth attributes. Pigeonpea+sorghum leads to more competition for nutrient, water space etc. and thus recorded lower values. Rajkhowa et al. (2002) and Kantwa et al. (2005) were found higher Pigeonpea yield in pigeonpea+urdbean as compare to sole pigeonpea.

Application of $100 \% \mathrm{RDF}+2.5 \mathrm{t} \mathrm{VC}$ was recorded maximum plant height $\left(232.42 \mathrm{~cm} \mathrm{plant}^{-1}\right)$, number of branches (19.07 plant $\left.^{-1}\right)$, plant dry matter accumulation (214.65 gm plant $^{-1}$ ), LAI (3.62), effective root nodule (24.42 plant $\left.^{-1}\right)$, nodule dry weight $\left(185.80 \mathrm{mg} \mathrm{plant}^{-1}\right)$ and days to maturity (265.17) over all the other treatments. The number of nodule was found at par on $100 \% \mathrm{RDF}+\mathrm{PSB}+$ rhizobium and 50\% RDF. The plant dry matter accumulation was found at par on different fertility levels at $100 \%$ RDF, $50 \%$ $\mathrm{RDF}+\mathrm{PSB}+\mathrm{rhizobium}$ a nd $100 \%$ $\mathrm{RDF}+\mathrm{PSB}+$ rhizobium, $50 \% \mathrm{RDF}+2.5 \mathrm{t} \mathrm{VC}$. The effective root nodule was found at par at $100 \% \mathrm{RDF}, 50 \%$ $\mathrm{RDF}+\mathrm{PSB}+$ rhizobium. The nodule dry weight was found at par at $100 \%$ RDF, $50 \%$ $\mathrm{RDF}+\mathrm{PSB}+$ rhizobium. Days to maturity was found at par at $100 \% \mathrm{RDF}, 50 \% \mathrm{RDF}+\mathrm{PSB}+$ rhizobium. The experimental findings showed that growth characters like plant height $(\mathrm{cm})$, number of branches plant ${ }^{-1}$, dry matter plant $^{-1}(\mathrm{~g})$, LAI, effective root nodule plant ${ }^{-1}$, Nodule dry weight plant ${ }^{-1}(\mathrm{mg})$ and days to maturity at various stages have positive relation with the fertility levels. The maximum growth attributes were found with $100 \% \mathrm{RDF}+2.5 \mathrm{t} \mathrm{VC}$ and this treatment being significantly superior over rest of all the treatments (Fig.1). Significantly higher values of all these attributes in all the component crops were recorded in the treatment receiving combined use of vermicompost @ $2.5 \mathrm{t} \mathrm{ha}^{-1}+50 \%$ RDF. However, it was comparable with the treatment receiving 50\% RDF along with $2.5 \mathrm{t}$ ha $^{-1}$ phosphocompost (Sharma et al., 2010: Patil and Padmani (2007); Singh and Pal (2003). 
Table 1. Effect of intercropping system and fertility levels on growth attributes of pigeonpea.

\begin{tabular}{|c|c|c|c|c|c|c|c|}
\hline Treatment & $\begin{array}{l}\begin{array}{l}\text { Plant } \\
\text { height } \\
\text { (cm) }\end{array} \\
\end{array}$ & $\begin{array}{l}\text { No. of branch } \\
\text { plant }^{-1}\end{array}$ & $\begin{array}{l}\text { Dry mat- } \\
\text { ter plant }^{-1} \\
\text { (g) }\end{array}$ & LAI & $\begin{array}{l}\text { Effective } \\
\text { root nodule } \\
\text { plant }^{-1} \\
\end{array}$ & $\begin{array}{l}\text { Nodule dry } \\
\text { weight plant }^{-1} \\
\text { (mg) }\end{array}$ & $\begin{array}{l}\text { Days to } \\
\text { maturity }\end{array}$ \\
\hline \multicolumn{8}{|l|}{ Inter cropping system } \\
\hline Pigeonpea + sorghum & 216.13 & 17.04 & 210.02 & 3.29 & 23.03 & 182.69 & 262.33 \\
\hline Pigeonpea + urdbean & 231.22 & 18.20 & 213.25 & 3.45 & 23.58 & 183.96 & 263.00 \\
\hline $\mathrm{SEm} \pm$ & 0.62 & 0.11 & 0.12 & 0.01 & 0.07 & 0.19 & 0.17 \\
\hline $\mathrm{CD}(\mathrm{P}=0.05)$ & 1.82 & 0.33 & 0.34 & 0.03 & 0.20 & 0.54 & 0.50 \\
\hline \multicolumn{8}{|l|}{ Fertility level } \\
\hline $100 \% \mathrm{RDF}$ & 217.90 & 16.98 & 210.65 & 3.31 & 22.97 & 182.48 & 262.33 \\
\hline $100 \% \mathrm{RDF}+2.5 \mathrm{t} \mathrm{VC}$ & 232.42 & 19.07 & 214.65 & 3.62 & 24.42 & 185.80 & 265.17 \\
\hline $\begin{array}{l}100 \% \text { RDF+PSB+ } \\
\text { Rhizobium }\end{array}$ & 228.38 & 17.93 & 212.57 & 3.38 & 23.35 & 183.48 & 261.33 \\
\hline $50 \% \mathrm{RDF}$ & 216.72 & 16.65 & 208.87 & 3.20 & 22.43 & 181.78 & 261.17 \\
\hline $50 \% \mathrm{RDF}+2.5 \mathrm{t} \mathrm{VC}$ & 225.80 & 17.87 & 212.30 & 3.46 & 23.92 & 184.20 & 263.83 \\
\hline $\begin{array}{l}50 \% \text { RDF } \\
+ \text { PSB+Rhizobium }\end{array}$ & 222.93 & 17.23 & 210.77 & 3.27 & 22.77 & 182.22 & 262.17 \\
\hline $\mathrm{SEm} \pm$ & 0.28 & 0.05 & 0.05 & 0.01 & 0.03 & 0.08 & 0.07 \\
\hline $\mathrm{CD}(\mathrm{P}=0.05)$ & 0.82 & 0.15 & 0.15 & 0.03 & 0.09 & 0.24 & 0.22 \\
\hline
\end{tabular}

Table 2. Effect of intercropping system and fertility levels on yield and yield attributes of pigeonpea.

\begin{tabular}{|c|c|c|c|c|c|c|c|c|c|}
\hline Treatment & $\begin{array}{l}\text { Pods } \\
\text { plant }^{-1}\end{array}$ & $\begin{array}{l}\text { Pod } \\
\text { weight } \\
\text { plant }^{-1} \\
\end{array}$ & $\begin{array}{l}\text { Weight of } \\
\text { grains } \\
\text { plant }^{-1}(\mathrm{~g})\end{array}$ & $\begin{array}{l}\mathbf{5 0 \%} \\
\text { flowering }\end{array}$ & $\begin{array}{l}\text { Grain } \\
\text { Pod }^{-1}\end{array}$ & $\begin{array}{l}\text { Test } \\
\text { weight } \\
\text { (g) } \\
\end{array}$ & $\begin{array}{l}\text { Grain } \\
\text { yield } \\
\left(\mathrm{kg} \mathrm{ha}^{-1}\right)\end{array}$ & $\begin{array}{l}\text { Stalk } \\
\text { yield } \\
\left(\mathrm{kg} \mathrm{ha}^{-1}\right)\end{array}$ & $\begin{array}{l}\text { Harvest } \\
\text { index } \\
(\%)\end{array}$ \\
\hline \multicolumn{10}{|c|}{ Inter cropping system } \\
\hline $\begin{array}{l}\text { Pigeon- } \\
\text { pea+sorghum }\end{array}$ & 131.40 & 110.90 & 106.96 & 141.17 & 3.46 & 103.07 & 1659.04 & 7159.58 & 18.81 \\
\hline $\begin{array}{l}\text { Pigeon- } \\
\text { pea+Urdbean }\end{array}$ & 135.57 & 114.62 & 108.74 & 142.67 & 4.06 & 106.07 & 1792.29 & 7614.97 & 19.05 \\
\hline $\mathrm{SEm} \pm$ & 0.22 & 0.28 & 0.25 & 0.186 & 0.04 & 0.15 & 9.48 & 40.16 & 0.01 \\
\hline $\begin{array}{l}\mathrm{CD}(\mathrm{P}=0.05) \\
\text { Fertility level }\end{array}$ & 0.64 & 0.85 & 0.75 & 0.544 & 0.10 & 0.44 & 27.81 & 117.80 & 0.03 \\
\hline $100 \%$ RDF & 130.55 & 113.90 & 109.04 & 142.00 & 3.70 & 103.12 & 1667.03 & 7179.31 & 18.84 \\
\hline $\begin{array}{l}100 \% \mathrm{RDF}+2.5 \mathrm{t} \\
\mathrm{VC}\end{array}$ & 141.42 & 115.73 & 110.71 & 145.67 & 4.13 & 108.22 & 1831.82 & 8221.61 & 18.21 \\
\hline $\begin{array}{l}100 \% \\
\text { RDF+PSB+ } \\
\text { Rhizobium }\end{array}$ & 134.70 & 111.73 & 106.91 & 142.33 & 3.77 & 105.63 & 1723.68 & 7560.75 & 18.56 \\
\hline $50 \%$ RDF & 126.02 & 111.90 & 106.00 & 139.17 & 3.53 & 101.03 & 1623.53 & 6624.94 & 19.66 \\
\hline $\begin{array}{l}50 \% \mathrm{RDF}+2.5 \mathrm{t} \\
\mathrm{VC}\end{array}$ & 136.70 & 114.40 & 109.30 & 142.00 & 3.82 & 105.42 & 1785.25 & 7541.77 & 19.14 \\
\hline $\begin{array}{l}50 \% \text { RDF } \\
+ \text { PSB+ Rhizo- } \\
\text { bium }\end{array}$ & 131.53 & 108.90 & 105.20 & 140.33 & 3.62 & 103.98 & 1722.68 & 7195.27 & 19.32 \\
\hline $\operatorname{SEm} \pm$ & 0.10 & 0.13 & 0.11 & 0.083 & 0.02 & 0.07 & 4.24 & 17.96 & 0.01 \\
\hline $\mathrm{CD}(\mathrm{P}=0.05)$ & 0.29 & 0.40 & 0.33 & 0.243 & 0.05 & 0.20 & 12.43 & 52.68 & 0.02 \\
\hline
\end{tabular}

Pigeonpea+urdbean intercropping always showed highest yield attributes that decreased in pigeonpea+sorghum intercropping system (Table 2). The highest values of yield attribute of pigeonpea i.e. no. of pods (135.57 plant $\left.^{-1}\right)$, no. of grains $\left(4.06\right.$ pod $\left.^{-1}\right)$, test weight (106.07g), 50\% flowering (142.67), pod weight $\left(114.62 \mathrm{~g} \mathrm{plant}^{-1}\right)$ and weight of grains (108.74 $\mathrm{g} \mathrm{plant}^{-}$ $\left.{ }^{1}\right)$. It might be due to varying competition between intercrops for light, moisture, nutrient and space with increasing in plant density more reduction in yield attributes of pigeonpea were found when it was intercropped with sorghum .This may be attributed to smothering and more competitive effect of sorghum for longer period of pigeonpea.

Yield attributing parameters like no. of pods (141.42 plant $\left.^{-1}\right)$, no. of grain $\left(4.13\right.$ pod $\left.^{-1}\right)$, test weight $(108.22 \mathrm{~g}), \quad 50 \%$ flowering (145.67), pod weight $\left(115.73 \mathrm{~g} \mathrm{plant}^{-1}\right)$, weight of grains $\left(110.71 \mathrm{~g} \mathrm{plant}^{-1}\right)$ were found superior in $100 \% \mathrm{RDF}+2.5 \mathrm{t} \mathrm{VC}$ than rest of all the treatment. It might be due to varying competition between fertility levels for light ,moisture, nutrient and space with increasing in plant density more reduction in yield attributes of pigeonpea were found when $50 \%$ RDF was applied.This may be attributed to smothering and more competitive effect of sorghum for longer period of pigeonpea. The application of 50\% $\mathrm{RDF}+5 \mathrm{t} \mathrm{FYM} \mathrm{ha}{ }^{-1}$ remained at par with $10 \mathrm{t} \mathrm{FYM} \mathrm{ha}^{-}$ $1,100 \%$ RDF and recorded significantly higher grain yield (26.5 q ha $\left.{ }^{-1}\right)$, and stalk yield (98.4 $\mathrm{q} \mathrm{ha}^{-1}$ ) of pigeonpea (Singh, 2007; Patil and Padmani, 2007). The 
maximum grain yield, stalk yield and biological yield of pigeonpea was recorded maximum under pigeonpea+urdbean intercropping system. In intercropping system, when plant density of pigeonpea reduced under pigeonpea+sorghum intercropping i.e. grain yield of pigeonpea reduced. The maximum grain yield $\left(1792.29 \mathrm{~kg} \mathrm{ha}^{-1}\right)$, stalk yield $\left(7614.97 \mathrm{~kg} \mathrm{ha}^{-1}\right)$ and harvest index $(19.07 \%)$ was found superior in pigeonpea+urdbean intercropping than pigeonpea + sorghum intercropping system. The maximum grain yield $\left(1831.82 \mathrm{~kg} \mathrm{ha}^{-1}\right)$, stalk yield $\left(8221.61 \mathrm{~kg} \mathrm{ha}^{-1}\right)$ and harvest index $(18.21 \%)$ was recorded superior at $100 \% \mathrm{RDF}+2.5 \mathrm{t} \mathrm{VC}$ over all the fertility levels (Fig. 2).

Interaction effect: Significant interaction was observed between the intercropping system and fertility levels on grain yield of pigeonpea during the experiment (Table 3). The higher grain yield was recorded

Table 3. Effect of interaction between intercropping $x$ fertility levels on grain yield $\left(\mathrm{kg} \mathrm{ha}^{-1}\right)$ of pigeonpea attributes.

\begin{tabular}{lll}
\hline Treatment & $\begin{array}{l}\text { Pigeon- } \\
\text { pea+Sorghum }\left(\text { IS }_{1}\right)\end{array}$ & $\begin{array}{l}\text { Pigeon- } \\
\text { pea+Urdbea } \\
\text { n }\left(\text { IS }_{2}\right)\end{array}$ \\
\hline 100\% RDF & 1621.27 & 1712.80 \\
100\% RDF+2.5t & 1742.13 & 1929.97 \\
VC & & \\
100\% RDF+PSB+ & 1656.63 & 1786.27 \\
Rhizobium & 1596.83 & 1644.60 \\
50\% RDF & 1701.30 & 1871.40 \\
50\% RDF+2.5t & & \\
VC & 1635.20 & 1810.07 \\
50\% RDF +PSB+ & \\
Rhizobium & 3.69 & \\
SEm \pm & 10.83 & \\
CD(P $=0.05)$ &
\end{tabular}

when pigeonpea intercropped with urdbean in association with the application of $100 \% \mathrm{RDF}+2.5 \mathrm{t} \mathrm{VC}$, which was $13.87 \%$ higher over pigeonpea + sorghum intercropping system at same level of fertility. However, yield of pigeonpea was not reduced to significant levels when grown in association with urdbean. This might be an indication of legume effect, because of associated legume (urdbean) might be full filling nitrogen requirement of pigeonpea, thus confirming that the interaction of intercropping system (pigeonpea + blackgram) and integrated nutrient (100\% RDF + 50\% RDN $+5 \mathrm{~kg} \mathrm{Zn} \mathrm{ha}^{-1}$ ) was significantly higher as compared to either sole cropping or without nutrient application in pigeonpea crop Kumawat et al. (2012).

Correlation studies: Association among traits measured by correlation coefficient revealed a significant and positive correlation (Table 4$)$. Dry matter $(0.946 \mathrm{~g}$ plant $\left.^{-1}\right)$, no. of branches $\left(0.938\right.$ plant $\left.^{-1}\right)$, no. of pods $\left(0.943\right.$ plant $\left.^{-1}\right)$, no. of grains $(0.902)$ and test weight (0.951) were significantly and positively correlated with grain yield. Pod weight $\left(0.592 \mathrm{~g} \mathrm{plant}^{-1}\right)$ and grain weight $\left(0.663 \mathrm{~g} \mathrm{plant}^{-1}\right)$ were not correlated with the grain yield of pigeonpea. The nodule weight plant $^{-1}$ and effective nodule plant $^{-1}$ was positively correlated with correlation co-efficient of 0.976 (Fig.3). This was further supported by the regression analysis. Thus, unit increase in effective nodule plant $^{-1}$ caused increase in nodule weight plant ${ }^{-1}$ by $2.00 \mathrm{mg}$ plant $^{-1}$ (Fig 2). Each unit increase in effective nodule results in an increment in nodule weight was also reported by Sahay et al. (2011). However, increased in each unit effective nodule plant ${ }^{-1}$ which leads to improved test weight by $3.186(\mathrm{~g})$ and proved with the regression analysis, which showed positive correlation co-efficient of

Table 4. Correlation coefficient study among yield attributes and yields of pigeonpea attributes.

\begin{tabular}{|c|c|c|c|c|c|c|c|c|}
\hline & $\begin{array}{l}\text { Grain } \\
\text { yield } \\
\left(\mathrm{kg} \mathrm{ha}^{-1}\right)\end{array}$ & $\begin{array}{l}\text { Dry mat- } \\
\text { ter plant }^{-1} \\
\text { (g) }\end{array}$ & $\begin{array}{l}\text { No. of } \\
\text { branch } \\
\text { plant }^{-1}\end{array}$ & $\begin{array}{l}\text { Pod } \\
\text { weight } \\
\text { plant }^{-1}(g)\end{array}$ & $\begin{array}{l}\text { Grains } \\
\text { weight } \\
\text { plant }^{-1} \text { (g) }\end{array}$ & $\begin{array}{l}\text { Pods } \\
\text { plant }^{-1}\end{array}$ & $\begin{array}{l}\text { Grain } \\
\text { Pod }^{-1}\end{array}$ & $\begin{array}{l}\text { Test } \\
\text { weight } \\
\text { (g) }\end{array}$ \\
\hline Grain yield $\left(\mathrm{kg} \mathrm{ha}^{-1}\right)$ & $1.000 * *$ & & & & & & & \\
\hline Dry matter plant $^{-1}(\mathrm{~g})$ & $0.946 * *$ & $1.000 * *$ & & & & & & \\
\hline No.of branch plant ${ }^{-1}$ & $0.938 * *$ & $0.983 * *$ & $1.000 * *$ & & & & & \\
\hline Pod weight plant ${ }^{-1}(\mathrm{~g})$ & 0.592 & 0.652 & 0.642 & $1.000 * *$ & & & & \\
\hline $\begin{array}{l}\text { Grains weight plant } \\
\text { (g) }\end{array}$ & $0.663^{*}$ & $0.719^{*}$ & $0.700 *$ & $0.946^{* *}$ & $1.000 * *$ & & & \\
\hline Pods plant ${ }^{-1}$ & $0.943 * *$ & $0.961 * *$ & $0.963 * *$ & 0.618 & $0.744^{*}$ & $1.000 * *$ & & \\
\hline Grain pod ${ }^{-1}$ & $0.902 * *$ & $0.937 * *$ & $0.919 * *$ & $0.782 * *$ & $0.766^{* *}$ & $0.846^{* *}$ & $1.000 * *$ & \\
\hline Test weight (g) & $0.951 * *$ & $0.990 * *$ & $0.981 * *$ & 0.574 & 0.676 & $0.981 * *$ & $0.889 * *$ & $1.000 * *$ \\
\hline
\end{tabular}

Note: Correlation coefficient is significant at $* \mathrm{P}=0.05$ and $* * \mathrm{P}=0.01$ level of significance.

Table 5. Correlation coefficient ( $\mathrm{r})$ and regression equations $\left(\mathrm{R}^{2}\right)$ showing relationship between dependent and independent variables.

\begin{tabular}{|c|c|c|c|c|}
\hline Dependent variable & Independent variable & $\mathbf{r}$ & $\mathbf{R}^{2}$ & Response equation \\
\hline \multirow[t]{6}{*}{ Grain yield $\left(\mathrm{kg} \mathrm{ha}^{-1}\right)$} & Dry matter plant $^{-1}(\mathrm{~g})$ & $0.946^{* *}$ & 0.894 & $Y=0.024 x+169.9$ \\
\hline & No. of branch plant ${ }^{-1}$ & $0.938 * *$ & 0.879 & $Y=0.010 x+0.203$ \\
\hline & Pod weight plant ${ }^{-1}(\mathrm{~g})$ & 0.592 & 0.350 & $Y=0.018 x+81.23$ \\
\hline & Grains weight plant ${ }^{-1}(\mathrm{~g})$ & $0.663 *$ & 0.439 & $Y=0.016 x+78.85$ \\
\hline & Pods plant $^{-1}$ & $0.943 * *$ & 0.889 & $Y=0.059 x+31.07$ \\
\hline & Test weight (g) & $0.951 * *$ & 0.904 & $Y=0.028 x+55.2$ \\
\hline
\end{tabular}

Note: Correlation coefficient is significant at $* \mathrm{P}=0.05$ and $* * \mathrm{P}=0.01$ level of significance. 
0.861 (Fig.4). However, correlation coefficient (r) and regression equations $\left(\mathrm{R}^{2}\right)$ showing relationship between independent and dependent variables were also computed and presented in table 5.

\section{Conclusion}

The pigeonpea+urdbean intercropping system exhibited its superiority by recording higher growth and yield attributes of pigeonpea crop. Application of $100 \% \mathrm{RDF}+2.5 \mathrm{t} \mathrm{VC}$ fertility level recorded its superiority by recording higher yield attributes over all fertility levels. So, pulse based intercropping system with integrated nutrient management may improve either pigeonpea crop or intercrop yield as compared to sole cropping system and nutrient application.

\section{REFERENCES}

Bouyoucos, G.J. (1962). Hydrometer method improved for making particle size analyses of soils. Agron. J. 54 : 464-465.

GOI. (2011). Directorate of Economics and Statistics. Department of Agriculture and Cooperation, Govt. of India.

Gomez, K.A. and Gomez, A.A. (1984). Statistical procedures for Agricultural Research ( $2^{\text {nd }}$ ed., 1984). John Wiley and Sons Inc., New York, U. S. A.

Jackson, M.L. (1967). Soil Chemical Analysis. Prentice Hall of India Pvt. Ltd., New Delhi.

Jackson, M.L. (1973). Soil Chemical Analysis. Prentice Hall of India Pvt. Ltd, New Delhi. 498.

Kantwa, S.R., Ahlawat, I.P.S. and Gangaiah, B. (2005). Effect of land configuration, post-monsoon irrigation and phosphorus on performance of sole and intercropped pigeonpea. Ind. J. Agro. 50 (4) : 278-280.

Kumar, A. and Rana, K.S. (2007). Performance of pigeonpea
(Cajanus cajan) + greengram (Phaseolus radiatus) intercropping system as influenced by moisture - conservation practices and fertility level under rainfed conditions. Ind. J. Agro. 52 (1) : 31-35.

Kumawat, N., Singh, R.P., Kumar, R., Kumari, A. and Kumar, P. (2012). Response of intercropping and integrated nutrition on production potential and profitability on rainfed pigeonpea. J. Agri. Sci. 4 (7) : 154-162.

Olsen, S.R., Cole, C.V., Wantanable, F.S. and Dean, L.A. (1954). Estimation of available phosphorus in soil by extraction with Sodium bicarbonate. United State Dept. of Agric. CIRC., Washinton, D.C., 939.

Patil, A.B. and Padmani, D.R. (2007). Effect of integrated nutrient management on growth and yield of pigeonpea (Cajanus cajan L. Millsp.). Inter. J. Agri. Sci. 3 (2) : 4951.

Rajkhowa, D.J., Saikia, M. and Rajkhowa, K.M. (2002). Effect of vermicompost with and without fertilizer on greengram. Leg. Res. $25: 295-296$.

Sahay, R., Chandra, R., Kumar, S. and Upadhyay, R. K. (2011). Influence of Rhizobacteria on the performance of urdbean (Vigna mungo) Rhizobium symbiosis. Crop Res. (Hisar), 42 (1/2/3) : 90-93.

Sharma, A., Rathod, S.P. and Chavan, M. (2010) Integrated nutrient management in pigeonpea (Cajanus cajana) based intercropping systems under rainfed conditions. Karnataka J. Agric. Sci., 23 (4) : 584-589.

Singh, R.S. (2007). Effect of organic and inorganic sources of nutrition on productivity of long duration pigeonpea (Cajanus cajan (L.) Millsp.). Enviro. Eco. 25S (Special 3A) : 768-770.

Singh, T. and Pal, M. (2003). Growth parameters, yield attributes and yield of pigeonpea as influenced by cropping systems and Nitrogen + Phosphorus levels. Ann. Agri. Res. 24 (4) : 755-759.

Subbiah, B.V. and Asija, G.L. (1956). A rapid procedure for the estimation of available nitrogen in soil. Curr. Sci. $25: 259$. 